\title{
Developing Energy Conversion Teaching Material Based on Discovery Learning Model Through Scientific Approach
}

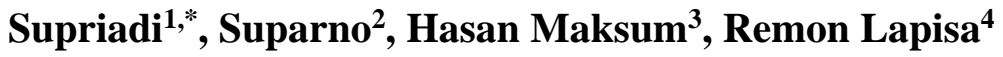 \\ 1,2,3,4 Faculty of Engineering, Padang State University, Padang-Indonesia \\ *Corresponding author: supriadi.fkip@gmail.com
}

\begin{abstract}
Energy conversion material is material that requires a more detailed and broad understanding and explanation of the material. To be able to improve students' understanding, a discovery learning model teaching material is needed through a scientific approach oriented to problems related to real life. The purpose of this study is to produce teaching materials that are valid, practical and effective in the field. This type of research is research and development with a 4-D (four-D) development model. The subjects of this study were students of class X Automotive Light Vehicle Engineering Vocational High School 1 Padang. The instruments used were validation sheets, teacher and student response questionnaires, and learning achievement tests. The results obtained from this development research are as follows: (1) Generating teaching materials for discovery learning models through a scientific approach. (2) The results of the analysis of the validity of teaching materials to experts obtained an average of $0.910>0.667$ with a valid category, (3) The results of the practicality analysis of teaching materials from the teacher's response were $87.33 \%$ with a very practical category and students' responses were $91.26 \%$ with a very practical category (4) The results of the analysis of the effectiveness of teaching materials are assessed from the results of the pretest and posttest, the gained score is 0.59 in the medium category. The study provides evidence that discovery learning model teaching material through scientific approach is valid, practical and effective to use.
\end{abstract}

Keywords: teaching materials; discovery learning; scientific; validity; practicality; effectiveness

\section{Introduction}

Education is one of the pillars of a country's economic development, so to achieve an expansive economy there needs to be a good quality of education, then directly the country's workforce has an advantage in science. Education can make the workforce able to make their work effectively and efficiently. This facility can increase productivity and affect production optimally (Affandi, 2019). Education is one of the important things that must be fulfilled by every human being. Education is an effort to make people become better personalities and be able to overcome every problem that exists in the development of the world today, able to make skilled and skilled human resources in each field (Cristiyantoro, 2010). Education is inseparable from efforts to shape competent human resources. By carrying out human education can change the potential that exists in itself into a competency to face and solve problems in life.

Vocational education is an expensive investment, but it is very strategic in producing Indonesian people who are skilled and skilled in their fields according to the needs of the 
community and nation, especially the needs of the business and industrial world (Supriadi, 2002). Vocational education aims to equip students to have behavioral competencies in a particular vocational field, so that those concerned are able to work (have performance) for their future and nationality (Schippers \& Patriand, 1993). In terms of economic policy, vocational education provides a very large contribution in order to improve the quality and productivity of the business world and the national economic system, both quantitatively and qualitatively. Economic growth cannot be achieved without the availability of qualified and well managed human resources (Sutikno, 2014).

The 2013 curriculum is a follow-up to the curriculum set at the school known as the competency-based curriculum that has been used in the education system in Indonesia since 2004 (Mulyasa, 2015). The learning process in 2013 curriculum was carried out using a scientific approach. The steps of the scientific approach in the learning process include exploring information through observation, asking questions, experimenting, then processing data or information, presenting data or information, followed by analyzing, reasoning, concluding, and creating (Untari, 2015). The application of scientific approach to learning involves the process skills of observing, classifying, measuring, predicting, explaining, and concluding (Helsinki, 2006). The application of the revised edition of the 2013 curriculum requires students to be more active in learning to add insight to knowledge. One way is to read a lot so that the teaching materials used play an important role in the teaching and learning process. So that teaching materials are needed by teachers in teaching and students are needed to support the learning process (Mufidah, 2014).

The problem that often occurs in the educational process is the low learning outcomes of students. This is influenced by internal and external factors of students. Karwono and Mularsih (2018: 46) suggest that internal factors of student learning outcomes is factors that influence students learning outcome from within students themselves such as physiological and psychological factors, while external factors are influences originating from outside the student called the student environment.

One external factor that can affect student learning outcomes is teaching materials that are arranged systematically, displaying a complete competence to be mastered by students in the learning process, the aim, the plan and the implementation of learning (Meidy, 2018). Teaching material is learning material delivered by the teacher to students, so we need teaching material that is able to accommodate the learning purpose attainment (Devi, P. C. 
2018). Teaching materials are materials or subject matter that are arranged systematically, which are used by instructors and students in the learning process (Amin, 2016). Furthermore, teaching material is selected material that to be taught to students or teaching material to be learned and understood by students (Syutaridho, 2019). So it can be concluded teaching materials are materials or subject matter arranged systematically, which are used by teachers and students in the learning process.

The principles of developing instructional materials are conformity (Validity), importance (significance), usefulness (utility), and the possibility to be learned (learnability) (Mulyasa, 2016). Teaching Learning Materials made a shift from Response Strengthening to Knowledge Acquisition for the construction of Knowledge (Mukherjee, 2017). This shift requires teaching material to be equipped with instructional rules because it will be used by teachers to help and support the learning process. According to Prastowo (2011: 206), teaching materials make students more active, facilitate the implementation of teaching to students, and can minimize the role of educators. There are learning resources with teaching materials used, in developing teaching materials teachers must have innovations in making teaching materials that can get students' attention in increasing enthusiasm and passion.

One of learning models that increase enthusiasm and passion is discovery learning model (Susanti, 2018). According to Hosnan (2014: 280), the discovery learning model is one of the models developed in the 2013 curriculum. The discovery learning model is a learning model that connects problems that occur in the real world. The problem is used as a concept for students to produce critical and skilled ways of thinking in problem solving, as well as to gain knowledge. In principle, students are not given knowledge but students must discover new things themselves.

Research mentions several advantages of teaching material namely (1) students learning more effectively; (2) the class is more organized in doing the tasks given by the teacher; (3) the students are always on time in completing group assignments; (4) students find it easier to evaluate individually; (5) it easier for teachers to oversee the course of the learning process (Said, 2016).

Effective teaching materials can encourage students to learn independently so that student center learning can be implemented, but in its implementation there are still many teaching materials that have not been effective in the learning process. As observed by 
researchers at State Vocational High School 1 Padang Class X Competency in Light Vehicle Engineering Skills Energy Conversion Material. Observations made to teachers and students who are implementing learning. Based on observations made at Vocational High School 1 Padang shows that the teaching material used still comes from the publisher, contains a summary of material and a collection of questions that are difficult to understand, the lack of specific phenomena presented, a combination of colors that are less attractive, not using a scientific approach, and instructions for using instructional materials that are less clear, so students do not understand the contents of these teaching materials. This resulted in the function and benefits of teaching materials not as expected.

Preliminary study "conducted by researchers at Vocational High School 1 Padang, researchers get information about the constraints of the lack of teaching materials. Teaching materials "used by teachers are still in the form of presentations made by teachers so that students only take notes, sometimes students are told to search the internet in accordance with the material to be discussed. As has been said by the teacher of $\mathrm{X}$ class automotive basic technology namely the use of handouts printed by students from the internet and presentations presented by the teacher in learning have not been able to support the learning process and students become passive and learning is not centered again on the students. Learning is a process, an activity and not an outcome or goal. Learning is not just remembering, but also experiencing (Hamalik, 2015: 36). In addition, learning is also interpreted by Sudjana in (Jihad, 2013) as a process marked by changes in a person, changes as a result of the process of learning can be shown by various forms such as changes in knowledge, understanding, attitudes and behavior, skills, abilities, habits, and changes in aspects that exist in individuals.

Teaching materials used in Vocational High School 1 Padang have not been able to support independent learning, it is not self-contained, and does not enables experiencing, so students only rely on the learning process. When students rely solely on the learning process in class, it has an impact on the failures of learning. As an example, the results of the Final Examination of class X in semester January - June 2019 shows that the average success rate of each basic competency is only around $60.92 \%$. The problem is an average of $39.08 \%$ of students who fail are required to repeat again.

The main objective of the development of this teaching material is to increase students' understanding of the subject matter which has an impact on decreasing failure rates 
and improving student learning outcomes. Development of teaching materials by using discovery learning models through a scientific approach is expected to minimize these problems. By utilizing teaching material in learning, it will be able to support learning independently with high mobility. Thus, the purpose of this research is to produce teaching materials for discovery learning models through a scientific approach to energy conversion material in Vocational High School 1 Padang which is valid, practical and effective for student learning outcomes.

\section{Materials and Methods}

This research used Research and Development methods. Research and development is a research method used to produce certain products, and test the effectiveness of these products (Sugiyono, 2018: 297). The resulting product was analyzed and its effectiveness was tested so that it can be used in the wider community.

This research used a 4-D (four-D) development model developed by Thiagarajan, Semsel, and Semsel (1974: 5). This model was chosen because it has a simple procedure, has a systematic procedure which is in accordance with the steps of research development needed. This development model includes 4 stages of determining, designing, developing, and disseminating. The design phase was carried out to design an energy conversion teaching materials based on discovery learning models through a scientific approach. This design phase included two steps, namely the selection of the format and design of teaching materials, the format of teaching materials started from the front cover of teaching materials to the back cover of teaching materials. Designing teaching materials was the activity of designing teaching models or physical teaching materials to make them more interesting and motivate students to learn. The development phase aimed to produce teaching materials for the discovery learning model through a scientific approach to energy conversion material for basic automotive technology subjects that meet the requirements. The feasibility of this teaching material was measured through the study of suggestions or input and validation by experts, namely material aspects, language aspects and graphic aspects. Practicality of teaching materials was measured through the results of teacher and student responses after reading teaching materials obtained from filling out questionnaires through limited trials.

The population of this research was class $\mathrm{X}$ Competence of Automotive Light Vehicle Engineering Expertise (TKRO) at Vocational High School 1 Padang in the academic 
year 2019/2020. There are three classes of class X Competence of Automotive Light Vehicle Engineering Expertise, namely class A, B and C. The samples was carried out after administering simple homogeneous abilities testing by looking at the classes' average score of midterm examinations. Class A had an average score of 56, Class B had an average score of 64 and class $\mathrm{C}$ had an average score of 58. Thus, it was found that the average score of Class $\mathrm{A}$ and $\mathrm{C}$ are not much different. Then, the two classes were taken as samples: class $\mathrm{A}$ as the experimental class and class $\mathrm{C}$ as the control class.

To develop the teaching material some data as the primary data of the study were required. Primary data is a data source that directly provides data to data collectors (Sugiyono 2018: 137). These data included the validity of teaching materials evaluated by the validator, practicality test questionnaires for teaching materials filled out by educators and students, and effectiveness tests obtained from the scores per Basic Competence in daily test results of student participants.

\section{Results and Discussion}

Comparison of this study with previous research. First, the methods used in the learning process are oriented towards the $5 \mathrm{M}$ scientific approach, secondly the teaching materials are developed according to new literacy (data, technology and human) Third, this research is in the valid, practical, and effective categories used in learning, research is not only up to just to development, but to test the effectiveness of teaching materials. Based on theoretical studies and relevant research studies above, it is known the benefits of developing discovery learning models through scientific approaches to energy conversion material are able to make students more active, can motivate good learning, and can improve student understanding in the learning process. The learning model through the scientific approach that was developed, can make it easier for teachers to provide learning materials, and give students an independent learning experience.

The reliability of the developed teaching material can be seen from the results of the experts validation. The validation was in the form of ranking scale from each validator. Expert validation was obtained from a closed questionnaire to assess the draft teaching material developed. Validation results can be seen in table 1 
Table 1 . The Eligibility of the developed teaching material

\begin{tabular}{cccccc}
\hline \multirow{2}{*}{ No } & \multirow{2}{*}{ Eligibility component } & \multicolumn{3}{c}{ Validator } & \multirow{2}{*}{ Average } \\
\cline { 3 - 4 } & Content eligibility & $\mathbf{1}$ & $\mathbf{2}$ & $\mathbf{3}$ & \\
\hline 1 & Eligibility of presentation & 1.00 & 0.87 & 0.80 & 0.89 \\
\hline 2 & Eligibility of languages & 1.00 & 0.92 & 0.83 & 0.92 \\
\hline 3 & Eligibility of graphics & 1.00 & 0.95 & 0.70 & 0.97 \\
\hline 4 & 1.00 & 0.92 & 0.78 & \multirow{2}{*}{0.91} \\
\hline \multicolumn{4}{c}{ Average Average } & & \\
\hline
\end{tabular}

Table 1 shows that the validity value of $1.00>0.67$ given by the 1 st validator, and a validity value of $0.92>0.67$ given by the $2^{\text {nd }}$ validator, and a validity value of $0.78>0.67$ given by the $3^{\text {rd }}$ validator. Azwar (2014) mentions that validity value $\geq 0,667$ is categorized as valid. Thus, it can be concluded that the discovery learning model teaching material through the scientific approach is valid as the average of the content, presentation, linguistic and graphic aspects of the three validators is 0.91 .

At this stage a field test was carried out to see the practicality of the developed teaching material. Practicality data was obtained from practical questionnaires filled in by subject teachers and students. At this stage a field test was carried out to see the practicality of Development of teaching material the discovery learning model through the scientific approach basic competency of energy conversion. Practicality test data was obtained from practical questionnaires filled in by subject teachers and students who were studying.

\section{Test Practicality}

a. The Teacher's Response To The Practicality Of Teaching Materials

Assessment of practitioners were carried out to obtain practicality. Questionnaires filled out by subject teachers regarding teaching material practicalities. The results of the teacher's response can be seen in Table 2. Below.

Table 2. practicality Based on Teacher Responses

\begin{tabular}{llcc}
\hline \multirow{2}{*}{ No } & Assessment Aspects & Average Value (\%) & Category \\
\hline 1 & Attractiveness & $86.67 \%$ & Very Practical \\
\hline 2 & Development Process & $90.00 \%$ & Very Practical \\
\hline 3 & Ease of Use & $90.00 \%$ & Very Practical \\
\hline 4 & Functioning and Use & $90.00 \%$ & Very Practical \\
\hline 5 & Reliability & $80.00 \%$ & Practical \\
\hline & Average & $87.33 \%$ & Very Practical \\
\hline
\end{tabular}


Based on Table 2, the average practicality value of teaching materials from the teacher's response was $87.33 \%$ which falls into the "very practical" category. So that the presentation of the data shows that the teaching material based on discovery learning models through the scientific approach is very practical, or easy to use for teachers.

b.Practicality Test of Student Response Teaching Materials

Practicality test was also obtained based on student responses. The following is a practicality test data table based on student responses.

Table 3. Practicality Based on Student Responses

\begin{tabular}{rlcc}
\hline No & \multicolumn{1}{c}{ Assessment aspect } & Average Value $(\%)$ & Category \\
\hline 1 & Attraction & $91,60 \%$ & Very Practical \\
\hline 2 & Ease of Use & $90,20 \%$ & Very Practical \\
\hline 3 & Functioning and Use & $92.00 \%$ & Very Practical \\
\hline & Average & $91.26 \%$ & Very Practical \\
\hline
\end{tabular}

Based on table 3 above, the average value of the practicality based on student responses is $91.26 \%$. So it can be concluded that the learning model is included in the "Very Practical" category. So the data shows that the use of discovery learning models through scientific approaches is very practical for students.

\section{Effectiveness Test}

The effectiveness of teaching material was seen by looking at student learning outcomes after administering tests on students. Tests were carried out twice, namely pretests conducted before using the developed teaching material and post test, the second test done after using the developed teaching material.

The average pretest of 30 students was 66.33 and the average posttest of 30 students was 87.00, the difference between the pretest and posttest score was 20.67. Presentation of learning outcomes obtained can be seen in table 4 below:

Table 4. Results of Pretest and Posttest

\begin{tabular}{ccccccc}
\hline \multirow{2}{*}{ No } & \multirow{2}{*}{ Activity } & \multirow{2}{*}{$\begin{array}{c}\text { Total } \\
\text { students }\end{array}$} & \multicolumn{2}{c}{ Learning outcomes } & \multicolumn{2}{c}{ Percentage } \\
\cline { 3 - 7 } & & Graduated & Not pass & Complete & Not pass \\
\hline 1 & Pretest & 30 & 7 & 23 & $23 \%$ & $77 \%$ \\
\hline 2 & Postest & 30 & 27 & 3 & $90,91 \%$ & $9.09 \%$ \\
\hline
\end{tabular}


Based on Table 4, the increasing number of students who passed the minimum score from pretest to post test was evidence. Hence, teaching material based on discovery learning model through a scientific approach is said to be effective as the gained score was 0.58 which was higher than 0.3 . The gain score analysis can be seen in table 5 .

Table 5. Recapitulation of Gain Score Value

\begin{tabular}{cccc}
\hline $\mathbf{N}$ & $\begin{array}{c}\text { Pretest } \\
\text { Average }\end{array}$ & Posttest Average & Gain Score \\
\hline 47 & 65.76 & 86.82 & 0.59 \\
\hline \multicolumn{7}{c}{ Category } & Medium \\
\hline
\end{tabular}

Based on the results of the pretest and posttest, the gained score 0.59 is obtained in the medium category, so it can be concluded that the teaching material of the discovery learning model through a scientific approach is declared effective.

\section{Conclusion}

The developed teaching material was declared to be valid after being validated by three validators. Besides, proven practical, the developed teaching material was also effective. The study provides evidence that the use of scientific approach in developing teaching material may provide positive impact. Thus, teachers are encouraged to use teaching material which is developed based on scientific approach to encourage discovery learning.

\section{References}

Affandi, A., SI, M. F., \& Risma, O. R. 2019. Analisis tingkat pendidikan dan TPAK Terhadap PDRB Perkapita di Indonesia. Jurnal Ekombis, 5(2).

Amin, M. (2016). Panduan Pengembangan Bahan Ajar IPA. Jakarta: Direktorat Jendral Dikdas.

Arikunto, Suharsimi (2010). Manajemen Penelitian. Jakarta : Rineka Cipta.

Azwar, Saifuddin. 2014. Metode Penelitian. Yogyakarta: Pustaka Pelajar.

Cristiyantoro, F. 2014. Pengembangan Modul Pembelajaran Kolega dan Pelanggan Kompetensi Dasar Memelihara Standar Penampilan Pribadi pada Siswa Kelas X-3 Administrasi Perkantoran di SMKN 2 Kediri. Jurnal Administrasi Perkantoran (JPAP), 2(2).

Daryanto, dan Dwicahyono, A. 2014. Pengembangan Perangkat Pembelajaran (Silabus, $R P P, P B H$, Bahan Ajar). Yogyakarta: Gava Media

Depdiknas. 2008. Panduan Pengembangan Bahan Ajar. Jakarta: Direktorat Jendral Manajemen Pendidikan Dasar dan Menengah. 
Devi, P. C. 2018. Pengembangan Bahan Ajar Menulis Teks Prosedur Kompleks dengan Model Pembelajaran Discovery Learning Menggunakan Media Audio Visual (Video) di Kelas XI SMA Negeri 1 Samarinda. Diglosia: Jurnal Kajian Bahasa, Sastra, Dan Pengajarannya, 1(2), 101-114.

Famie Darmawan, R. A. C. H. M. A. N. 2014. Penerapn model pembelajaran Discovery Learning untuk meningkatkan hasil belajar mata pelajaran produktif pokok materi menentukan pemain siswa kelas XI Teknik Produksi dan Penyiaran Program Pertelevisian SMKN 1 Surabaya. Jurnal Mahasiswa Teknologi Pendidikan, 5(3).

Hamalik, O. 2015. Kurikulum dan Pembelajaran. Jakarta: Bumi Aksara.

Helsinki, 2006. Teacher Education, School Effectiveness and Improve-ment.(Online), (www.doria.org, di-akses 1 Februari 2014).

Hosnan.2014. Pendekatan Saintifik dan Kontekstual dalam Pembelajaran Abad 21. Jakarta: Ghalia Indonesia.

Jihad, A. (2013). Evalusi Pembelajaran. Yogykarta: Multi Pressindo

Karwono, \& Heni Mularsih 2018. Belajar dan Pembelajaran. Depok: Rajawali Pers.

Majid, Abdul. 2014. Pembelajaran Tematik Terpadu. Bandung: PT Remaja Rosdakarya

Meidy, R. D., Patmanthara, S., \& Arifin, M. Z. 2018. Pengembangan Bahan Ajar Cetak dengan Model Discovery Learning untuk Mata Pelajaran Komputer dan Jaringan Dasar Kelas X. JP (Jurnal Pendidikan): Teori dan Praktik, 3(2), 126-133.

Izzatul Mufidah, C. 2014. Pengembangan Modul Pembelajaran Pada Kompetensi Dasar Hubungan Masyarakat Kelas X APK 2 di SMKN 10 Surabaya. Jurnal Administrasi Perkantoran (JPAP), 2(2).

Mukherjee, T. 2017. Teaching Materials and Teaching Aids. Journal Phatashala Amity Univercity India, 3 -14.

Mulyasa. 2016. Revolusi dan Inovasi Pembelajaran Sesuai Standar Proses. Bandung: Rosda.

Novita, F., \& Irawati, S. 2018. Peningkatan aktivitas dan hasil belajar melalui model discovery learning dengan pendekatan saintifik. Diklabio: Jurnal Pendidikan dan Pembelajaran Biologi, 2(2), 86-93

Prastowo, Andi. 2011. Panduan kreatif Membuat Bahan Ajar Inovati. Yogyakarta: DIVA Press

Purwanto, Ngalim. 2009. Prinsip-Prinsip dan Teknik Evaluasi Pengajaran. Bandung: PT Remaja Rosdakarya

Said, I. M., Sutadji, E., \& Sugandi, M. 2016. Pengembangan Bahan Ajar Berbasis Cooperative Learning dengan Pendekatan Saintifik untuk Siswa SMK Se-Kota Malang Program Keahlian Teknik Ototronik. Jurnal Pendidikan: Teori, Penelitian, dan Pengembangan, 1(2), 265-270. 
Schippers, U. \& Patriana, D.M. 1993. Pendidikan Kejuruan Indonesia. Bandung: PT. Angkasa.

Syutaridho. 2019. Pengembangan Bahan Ajar Bangun Datar dengan Pendekatan Contextual Teaching and Learning. Jurnal Pendidikan Matematika RAFA, 1 - 7

Sinambela, P. N. 2017. Kurikulum 2013 dan Implementasinya dalam Pembelajaran. Generasi Kampus, 6(2).

Sugiyono. 2017. Metode Penelitian dan Pengembangan Research and Development. Bandung: Alfabeta.

Sugiyono. 2018. Metode Penelitian Kuantitatif, Kualitatif, dan R\&D. Bandung : Alfabeta.

Supriadi, D. 2002. Sejarah Pendidikan Teknik \& Kejuruan di Indonesia, Membangun Manusia Produktif. Bandung: Rosdakarya.

Susanti, R. 2018. Pengembangan Bahan Ajar Interaktif pada Mata Pelajaran Kearsipan Kelas X Otomatisasi dan Tata Kelola Perkantoran di SMK PGRI 13 Surabaya. Jurnal Pendidikan Administrasi Perkantoran (JPAP), 6(3).

Sutikno, T. A. 2014. Manajemen Strategik Pendidikan Kejuruan dalam Menghadapi Persaingan Mutu. Teknologi dan Kejuruan: Jurnal teknologi, Kejuruan dan Pengajarannya, 36(1).

Thiagarajan, S; Semmel, D.S; \& Semmel, M.I. 1974. Instructional Develop-ment for Training Teachers of excep-tional children:Bloomington Indiana: Indiana University

Trianto. 2014. Mendesain Model Pembelajaran Inovatif Progresif. Jakarta: Kencana.

Untari, R. S., Mukhadis, A., \& Waras, W. 2015. Kesiapan guru SMK Program Keahlian Teknik Komputer Dan Informatika dalam pelaksanaan kurikulum 2013. Teknologi Kejuruan: Jurnal Teknologi, Kejuruan, dan Pengajarannya, 38(1). 